\title{
A RELATION BETWEEN NON-ESTERIFIED FATTY ACIDS IN PLASMA AND THE METABOLISM OF GLUCOSE
}

\author{
BY VINCENT P. DOLE \\ (From the Rockefeller Institute for Medical Research, New York City, N. Y.)
}

(Submitted for publication July 21, 1955 ; accepted August 17, 1955)

The concentration of non-esterified fatty acids (NEFA) in plasma increases after an injection of heparin (1). Apparently a lipase released into the blood $(2,3)$ hydrolyzes the neutral fat in chylomicrons (4) and promotes both the reduction of turbidity in the plasma and removal of fatty acids to tissues.

If the small amounts of NEFA normally present in blood arise from hydrolysis of circulating triglycerides, the concentration should remain constant or increase to some extent during spontaneous clearing of alimentary lipemia, depending on relative rates of liberation and removal. This expectation was not supported by the present work. In every case, after a mixed meal, NEFA fell sharply and remained below the fasting value for 2 or more hours; fat alone, when fed in sufficient quantity to produce gross lipemia, had no demonstrable effect on circulating NEFA. Feeding of glucose or injection of insulin caused a fall in concentration comparable to that occurring after the mixed meals, while the injection of epinephrine caused a marked rise.

\section{METHOD}

Inadequacies of existing techniques for measurement of NEFA made a new method desirable. The procedure described below is rapid and simple with about 3 per cent coefficient of variation on replicate analysis and a sensitivity sufficient for accurate titration of fatty acids in $1 \mathrm{cc}$. of plasma.

It appears to be quite specific for non-esterified fatty acids, at least with respect to other organic acids likely to enter plasma, but it cannot be regarded as absolutely reliable. For the present all that can be claimed is that NEFA are quantitatively extracted, that they represent by far the major part of the acidity and that the method can be used with the same confidence as has been given to the Davis method (5) or its various modifications $(3,6)$.

The extraction of lipides into a one-phase system and subsequent conversion of the system to two phases in the present method is similar in principle to the methanolchloroform technique previously described by Folch, Lees, and Sloane-Stanley (7), and represents only a slight modification of the heptane-ethanol method developed in this laboratory by Blankenhorn and Ahrens (8). Heptane is a more convenient solvent than chloroform because it carries the lipides into an upper phase from which aliquot samples are easily taken; isopropyl alcohol, used in the present method instead of ethanol, is more efficient in bringing together heptane and water into a single phase. As a further simplification, titration of the heptane aliquot is conducted in a second two-phase system without preliminary evaporation of solvent.

Extraction mixture: isopropyl alcohol 40 parts; heptane 10 parts; $1 \mathrm{~N} \mathrm{H}_{2} \mathrm{SO}_{4} 1$ part (all solvents redistilled). Titration mixture: 0.01 per cent thymol blue and 90 per cent ethanol in water, made by dilution of a stock 0.1 per cent thymol blue in water with 9 parts of redistilled ethanol. The titratable acidity of ethanol slowly increases over a period of several days, but is easily reduced to a minimum value by addition of alkali from the burette. A slight acidity, equivalent to about $2 \lambda$ of $0.018 \mathrm{~N} \mathrm{NaOH}$ per cc. of titration mixture, is required to expel carbon dioxide from the system during titration. Alkali: approximately $0.018 \mathrm{~N} \mathrm{NaOH}$, made by $1 / 100$ dilution of saturated $\mathrm{NaOH}$ with carbon dioxide-free distilled water. The alkali, protected with a soda lime column, is stored in a small reservoir mounted above a 0.100 cc. Rehberg burette. Fresh alkali, prepared each day of analysis, is calibrated by extraction and titration of standards of recrystallized palmitic acid in heptane.

As soon as possible after separation of plasma, $5 \mathrm{cc}$. of extraction mixture is added to $1 \mathrm{cc}$. of plasma in a glassstoppered tube and shaken vigorously for a moment. After standing 10 minutes or longer the system is divided into two phases by mixing into it an additional $2 \mathrm{cc}$. of heptane and $3 \mathrm{cc}$. of water. The phases should separate rapidly without centrifugation, forming a sharp interface. A 3-cc. aliquot of upper phase is transferred to a 15-cc. conical centrifuge tube containing $1 \mathrm{cc}$. of titration mixture, and titrated with the alkali. Nitrogen, delivered to the bottom of the tube with a fine glass capillary, expels carbon dioxide from the sample and keeps the two phases mixed during titration. As the green-yellow endpoint is approached the gas stream is interrupted from time to time for examination of the indicator color in the alcoholic phase. Good lighting, such as that given by a fluorescent light placed just above and in front of the tube, has been found helpful in reading the endpoint.

In one test of reproducibility a series of standards, ranging from 0 to $713 \mu \mathrm{Eq}$. per L., showed 2.6 per cent coefficient of variation between duplicate titrations of the same extract, and 3.6 per cent between titrations of separate extracts. The mean values fell on a straight line 
TABLE I

Acidity of plasma fractions separated in the preparative ultracentrifuge at different densities *

\begin{tabular}{l|c|c|c|c|c|c}
\hline \hline \multirow{4}{*}{ Position } & \multicolumn{5}{|c|}{ Density $\left(\mathrm{D}^{20}\right)$} \\
\cline { 2 - 7 } & \multicolumn{2}{|c|}{1.01} & \multicolumn{2}{|c}{1.07} & \multicolumn{2}{|c}{1.20} \\
\cline { 2 - 7 } & $\begin{array}{c}\mathrm{C} \\
\mu E q . / L .\end{array}$ & $\mathrm{C} / \mathrm{M}$ & $\begin{array}{c}\mathrm{C} \\
\mu E q . / L .\end{array}$ & $\mathrm{C} / \mathrm{M}$ & $\begin{array}{c}\mathrm{C} \\
\mu E q . / L .\end{array}$ & $\mathrm{C} / \mathrm{M}$ \\
\hline Top & 104 & 0.07 & 178 & 0.20 & 180 & 0.42 \\
Middle & 1,215 & 0.86 & 760 & 0.86 & 406 & 0.95 \\
Bottom & & & & & 549 & 1.28 \\
Pellet & 5,090 & 3.58 & lost & & none & \\
\hline
\end{tabular}

* $\mathrm{C}=$ concentration of acidity determined with present method.

$\mathrm{C} / \mathrm{M}=$ ratio of actual acidity to mean acidity of the whole tube. The first tube (1.01) contained untreated plasma. The second (1.07) and third (1.20) started with mixtures of plasma and 80 per cent sucrose in $\mathrm{D}_{2} \mathrm{O}$ in the bottom and middle parts, and a protein-free layer of the same density (sucrose in $\mathrm{D}_{2} \mathrm{O}$; phosphate buffer, $\mathrm{pH} \mathrm{7.4,}$ $\mu$ 0.1) in the top. Centrifuged in a swinging bucket rotor 26 hrs. $\times 123,600 \mathrm{G}$ at approximately $10^{8} \mathrm{C}$.

passing through the origin, thus excluding bias in the method. The single extraction technique of the present method and the modified Davis extraction (5) described by Grossman, Stadler, Cushing, and Palm (6) gave nearly identical values in one experiment: single extraction $691 \mu$ Eq. per L.; Grossman $702 \mu$ Eq. per L. It will be noted that the comparison is limited to methods of extraction, since both extracts were titrated as described above; evaporation of solvent before titration removes most or all of the volatile short chain fatty acids, whereas they remain to be titrated in a two-phase system.

In further tests of the procedure the final concentration of mineral acid was varied from 0.01 to $0.10 \mathrm{~N}$, the temperature was varied from $5^{\circ}$ to $37^{\circ} \mathrm{C}$. and the time was extended to 24 hours without significant changes in the titratable acidity of the heptane phase. Each of the following organic acids, extracted as described above, remained almost entirely in the aqueous phase; less than 2 per cent of the acidity added to any system could be recovered by titration of the heptane phase: $\alpha$-ketoglutaric, $\beta$-hydroxybutyric, indole acetic, succinic, glycerophosphate, citric, malic, ascorbic, pyruvic. On the other hand, incubation of plasma at $37^{\circ} \mathrm{C}$. before extraction did increase the extractable acidity at a rate of about $35 \mu \mathrm{Eq}$. per L. per hour, presumably by enzymatic hydrolysis of esterified fatty acids; the increase was prevented by addition of $0.1 \mathrm{M} \mathrm{CuSO}$, or ethanol. Heparinized plasma showed the same concentration of NEFA as aliquots of serum from the same bleeding; since the plasma could be separated more rapidly heparin was used as an anticoagulant in most experiments.

On ultrafiltration of plasma through a collodion membrane (Schleicher and Schuell) only 5 per cent of the titratable acidity passed into the filtrate. ${ }^{1}$ Fractionation of plasma in a preparative ultracentrifuge (Table I) showed a sedimentation of acidity approximating the calculated behavior of albumin. At the lowest density the acidity became concentrated in the pellet, leaving very little to be extracted from the creamy lipide-rich upper layer. Increasing proportions of acid were found in the upper layer at higher densities, but even at 1.20 the major part had moved to the bottom of the tube. During the 2 hours required to set up the experiment and the 26 hours of centrifugation at $10^{\circ} \mathrm{C}$. extractable acidity increased about 20 per cent; presumably the additional material became associated with protein in the same way as that originally present in the fresh plasma. The evidence from these experiments supports the belief that most of the acidity determined by the present method resides in albumin-bound fatty acids and that little or no hydrolysis of triglyceride occurs in the extraction or titration.

\section{RESULTS}

Non-esterified fatty acids of the plasma were determined in 82 subjects: 6 normal males, 57 male and female obese patients, 4 tuberculous women, 3 men with essential hyperlipemia, 3 children with active rheumatic fever, and 9 adult patients with various diseases (hyperthyroidism, mild diabetes, fever of unknown origin, sprue, bili-

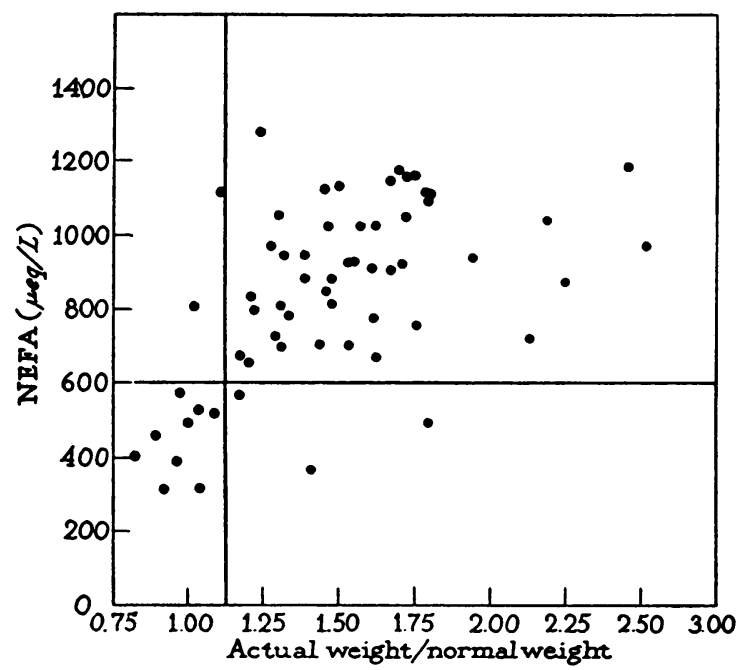

Fig. 1. Fasting Levels of Non-Esterified Fatty Acids in Plasma Related to the Degree of Obesity, the Latter Expressed as a Ratio between Actual Weight and Normal Weight for Age and Height (15)

1 Because almost all of the fatty acids in plasma are bound to protein it seems preferable to describe them as "non-esterified fatty acids," reserving the simpler term "free fatty acids" for the small but possibly important fraction actually free in solution. 
TABLE II

Plasma lipides of three fasting hyperlipemic men

\begin{tabular}{|c|c|c|c|c|c|c|c|}
\hline \multirow[b]{2}{*}{ Patient } & \multirow[b]{2}{*}{$\begin{array}{c}\text { NEFA } \\
\mu E q . / L .\end{array}$} & \multicolumn{2}{|c|}{ Triglyceride fat } & \multicolumn{2}{|c|}{ Cholesterol } & \multirow[b]{2}{*}{$\begin{array}{c}\text { Phospholipide } \\
\text { mg. \% }\end{array}$} & \multirow{2}{*}{$\begin{array}{c}\text { Total } \\
\text { lipides } \\
\text { mg. \% }\end{array}$} \\
\hline & & mg. \% & $m E q . / L .^{*}$ & $\begin{array}{c}\text { Free } \\
\text { mg. \% }\end{array}$ & $\begin{array}{l}\text { Total } \\
\text { mg. \% }\end{array}$ & & \\
\hline $\begin{array}{l}\text { A } \\
\text { B } \\
\text { C }\end{array}$ & $\begin{array}{l}875 \\
552 \\
486\end{array}$ & $\begin{array}{l}524 \\
565 \\
269\end{array}$ & $\begin{array}{l}19.5 \\
20.9 \\
10.0\end{array}$ & $\begin{array}{r}224 \\
85 \\
144\end{array}$ & $\begin{array}{l}731 \\
282 \\
526\end{array}$ & $\begin{array}{l}516 \\
306 \\
394\end{array}$ & $\begin{array}{l}2,110 \\
1,285 \\
1,445\end{array}$ \\
\hline Normal range & $500-900$ & $300-40 c$ & & & $150-250$ & $150-250$ & $600-1000$ \\
\hline
\end{tabular}

* Assuming the average equivalent weight of esterified fatty acid to be 270 .

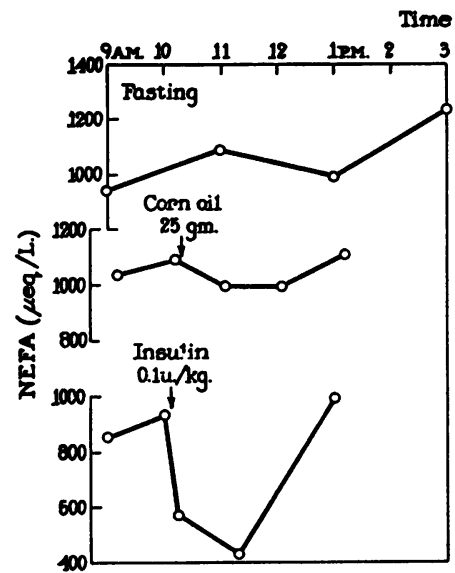

2

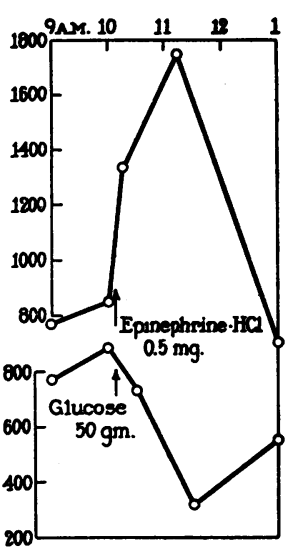

3

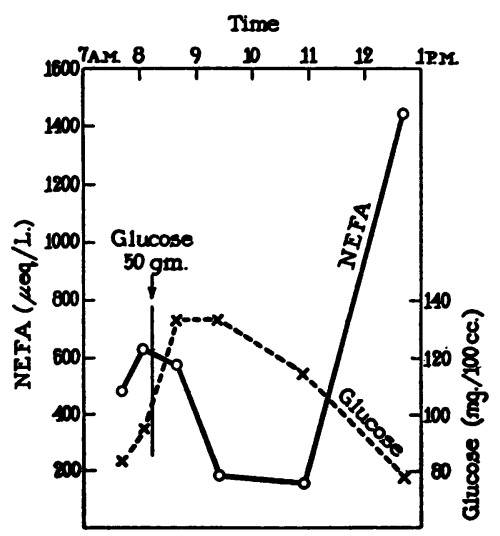

Fig. 2. Effects of Fasting (Average of Eight Experiments), Corn OIL (Four Experiments) aNd INSUlin (Four Experiments) ON Concentration of NonEsterified Fatty Acids

Fig. 3. Effects of Epinephrine (Three ExperiMents) and Glucose (14 Experiments) on Concentration of Non-Esterified Fatty Acids in Plasma

Fig. 4. Reciprocal Variations of Glucose and NoNEsterified Fatty Acids in Plasma after Ingestion of Grucose ary cirrhosis with marked reduction of liver function, Wilson's disease).

Fasting levels of NEFA, as determined in the morning after a 10 to 12 hour fast, ranged from 315 to $1210 \mu \mathrm{Eq}$. per L. Obese subjects tended to have high concentrations at the beginning of the day; for example, the fasting level exceeded $600 \mu \mathrm{Eq}$. per L. in 94 per cent of overweight people (ratio of actual weight to normal weight greater than 1.12), but reached this figure in only 18 per cent of those who were thinner (Figure 1). Excluded from this comparison are 2 patients with hyperthyroidism, 2 others with chronic low fever of unknown origin and 1 with sprue; these patients also showed high values, averaging 1100 $\mu$ Eq. per L. On the other hand, 3 hyperlipemic men had normal levels of NEFA despite high concentrations of other lipide fractions in their plasmas (Table II).

With continued fasting the concentration of NEFA rose slowly (Figure 2). By 3 PM a group of 8 obese women reached an average level of $1240 \mu \mathrm{Eq}$. per L., while 4 thin women averaged $930 \mu \mathrm{Eq}$. per L.-a concentration approximately equal to the morning average of the obese subjects.

A mixed meal eaten after a period of fasting invariably reduced the concentration of NEFA. One hour after a hospital breakfast, or lunch if breakfast had been omitted, the level had fallen from $850 \pm 330$ to $400 \pm 160 \mu \mathrm{Eq}$. per L. (12 patients, p. $<0.01)$. Following a single feeding of liquid formula ( 300 calories, of which 50 per cent from fat, 40 per cent carbohydrate, 10 per cent protein) (9) given to a group of 8 obese women, the NEFA fell from $1200 \pm 240$ to $790 \pm$ $220 \mu$ Eq. per L. (p. $<0.01$ ). 
Fat alone, when taken orally by fasting subjects, failed to increase the concentration of NEFA to any greater extent than fasting during the same period of time. Four obese subjects given 25 gm. of corn oil showed only a slight elevation or none at all, the maximum rise to $1245 \mu \mathrm{Eq}$. per L. being less than that encountered in a number of fasting subjects. In two other experiments 50 gm. of corn oil, emulsified with $5 \mathrm{gm}$. of Ethofat 60/20 (Armour and Co.), caused marked lipemia with increase in the optical density of plasma at $600 \mathrm{mu}$ from 0.06 to 0.37 , but had no effect on the concentration of non-esterified fat (Table III).

Glucose, on the other hand, caused a marked decrease in level, $850 \pm 220$ to $290 \pm 160 \mu \mathrm{Eq}$. per L. (p. $<0.001$ ), even greater than that seen after a mixed meal. A dose of $50 \mathrm{gm}$., given orally or intravenously, reduced NEFA to a minimum of approximately $200 \mu \mathrm{Eq}$. per L. (Table III), reached about $1 \frac{1}{2}$ hours after ingestion and followed by a slow return to the initial value. Obese subjects, with higher fasting concentrations, showed the greatest changes in concentration, but in all cases the administration of glucose caused some reduction in level. Measurement of both glucose concentration and NEFA in three experiments showed a closely correlated reciprocal vari- ation, illustrated by the curves in Figure 4 . It will be noted that the amount of glucose administered in these experiments provided less than half the number of dietary calories that had produced no effect in the form of fat.

Insulin, like glucose, caused a sharp drop when injected subcutaneously in a dose of $0.1 \mu$ per $\mathrm{kg}$., whereas in three other experiments an injection of epinephrine, $0.5 \mathrm{mg}$., produced the highest levels encountered in the entire study (Table III, Figures 2 and 3).

\section{DISCUSSION}

In a recent abstract (10) Grossman, Moeller, Palm, and McDaniel reported that the concentration of non-esterified fatty acids in plasma rose from 500 to $700 \mu \mathrm{Eq}$. per L. during periods of alimentary lipemia. The present results confirm the finding but cast some doubt on its relation to lipemia since comparable rises occurred when no fat was fed. In any case the changes in NEFA during fasting or after a fat meal were slight compared to the effects of glucose, insulin and epinephrine, and when both fat and glucose were given in a mixed meal the depressant effect of glucose predominated.

TABLE III

Non-esterified fatty acid in plasma $(\mu E q . / L$.$) *$

\begin{tabular}{|c|c|c|c|c|c|c|c|c|c|}
\hline \multirow[b]{3}{*}{ Procedure } & \multirow{3}{*}{$\begin{array}{l}\text { No. of } \\
\text { expts. }\end{array}$} & \multicolumn{8}{|c|}{ Time } \\
\hline & & \multicolumn{6}{|c|}{$\mathbf{A M}$} & \multicolumn{2}{|c|}{$\mathbf{P M}$} \\
\hline & & $7: 30$ & $8: 00$ & 9:00 & $10: 00$ & $10: 30$ & $11: 30$ & $1: 00$ & $3: 00$ \\
\hline Fasting & 8 & & & $\begin{array}{r}943 \\
\pm 240\end{array}$ & & & $\begin{array}{l}1,085 \\
\pm 231\end{array}$ & $\begin{array}{r}996 \\
\pm 242\end{array}$ & $\begin{array}{l}1,236 \\
\pm 196\end{array}$ \\
\hline $\begin{array}{l}\text { Glucose } \\
50 \mathrm{gm} .\end{array}$ & 14 & & & $\begin{array}{r}769 \\
\pm 120\end{array}$ & $\begin{array}{r}881 \\
\pm 219\end{array}$ & $\begin{array}{r}728 \\
\pm 254\end{array}$ & $\begin{array}{r}316 \\
\pm 164\end{array}$ & $\begin{array}{r}547 \\
\pm 342\end{array}$ & \\
\hline $\begin{array}{l}\text { Insulin } \\
0.1 \mu / \mathrm{kg} \text {. }\end{array}$ & 4 & & & $\begin{array}{r}854 \\
\pm 161 \\
\end{array}$ & $\begin{array}{r}933 \\
\pm 272 \\
\end{array}$ & $\begin{array}{r}567 \\
\pm 400 \\
\end{array}$ & $\begin{array}{r}438 \\
\pm 135 \\
\end{array}$ & $\begin{array}{r}988 \\
\pm 268 \\
\end{array}$ & \\
\hline $\begin{array}{l}\text { Epinephrine } \mathrm{HCl} \\
0.5 \mathrm{mg} \text {. }\end{array}$ & 3 & & & $\begin{array}{r}768 \\
\pm 18 \\
\end{array}$ & $\begin{array}{r}854 \\
\pm 80\end{array}$ & $\begin{array}{l}1,333 \\
\pm 378\end{array}$ & $\begin{array}{l}1,742 \\
\pm 346\end{array}$ & $\begin{array}{r}699 \\
\pm 276 \\
\end{array}$ & \\
\hline $\begin{array}{c}\text { Corn oil } \\
25 \mathrm{gm} .\end{array}$ & 4 & & & $\begin{array}{l}1,037 \\
\pm 108\end{array}$ & $\begin{array}{l}1,089 \\
\pm 168\end{array}$ & $\begin{array}{r}999 \\
\pm 115\end{array}$ & $\begin{array}{r}998 \\
\pm 162\end{array}$ & $\begin{array}{l}1,112 \\
\pm 134\end{array}$ & \\
\hline $\begin{array}{l}\text { Corn oil } \\
50 \mathrm{gm} .\end{array}$ & 2 & $\begin{array}{l}688 \\
438\end{array}$ & $\begin{array}{l}916 \\
454\end{array}$ & $\begin{array}{l}682 \\
585\end{array}$ & $\begin{array}{l}926 \\
505\end{array}$ & & $\begin{array}{r}1,042 \\
557\end{array}$ & $\begin{array}{l}916 \\
790\end{array}$ & \\
\hline
\end{tabular}

* Test material was fed or injected immediately after the last bleeding to the left of the vertical line. Values in all rows but the last are the mean and standard deviation of experiments in the group; the last row shows the primary data of two experiments. 
The responses of NEFA parallel the well-known effects of glucose (11), insulin (12), fasting (13) and epinephrine (14) on ketosis. Presumably both kinds of fatty acid-NEFA and ketone body -enter some metabolic process common to fat and carbohydrate.

\section{SUM MARY}

The concentration of non-esterified fatty acids in plasma increased with fasting, decreased after a mixed meal, oral glucose ( $50 \mathrm{gm}$.) or injected insulin $(0.1 \mu$ per $\mathrm{kg}$.), and rose markedly after injection of epinephrine $(0.5 \mathrm{mg}$.). Corn oil, on the other hand, failed to cause any change even when enough was taken to produce gross lipemia. The fasting levels of NEFA were normal in 3 men with chronic elevation of total plasma lipides, neutral fat, cholesterol and phospholipides.

A new method for determination of NEFA is described. It appears to be more rapid and sensitive than previous techniques.

\section{ACKNOWLEDGMENT}

The work was greatly helped by Dr. E. H. Ahrens, Jr., who gave many useful suggestions, and Dr. Rodes Trautman, who made the ultracentrifugal separation.

\section{REFERENCES}

1. Grossman, M. I., Palm, L., Becker, G. H., and Moeller, H. C., Effect of lipemia and heparin on free fatty acid content of rat plasma. Proc. Soc. Exper. Biol. \& Med., 1954, 87, 312.

2. Nichols, A. V., Freeman, N. K., Shore, B., and Rubin, L., The interaction of "heparin active factor" and lipoproteins. Circulation, 1952, 6, 457.

3. Shore, B., Nichols, A. V., and Freeman, N. K., Evidence for lipolytic action of human plasma obtained after intravenous administration of heparin. Proc. Soc. Exper. Biol. \& Med., 1953, 83, 216.
4. Weld, C. B., Proportion of protein to lipid in chylomicrons. Federation Proc., 1954, 13, 162.

5. Davis, B. D., The estimation of small amounts of fatty acid in the presence of polyoxyethylene sorbitan partial fatty acid esters ("Tween") and of serum proteins. Arch. Biochem., 1947, 15, 351.

6. Grossman, M. I., Stadler, J., Cushing, A., and Palm, L., Relation of lipolysis to deturbidification and returbidification in heparin-induced lipemia-clearing phenomenon. Proc. Soc. Exper. Biol. \& Med., 1955, 88, 132.

7. Folch, J., Lees, M., and Sloane-Stanley, G. H., A simple method for preparation of total pure lipide extracts from brain. Federation Proc., 1954, 13, 209.

8. Blankenhorn, D. H., and Ahrens, E. H., Jr., Extraction, isolation, and identification of hydrolytic products of triglyceride digestion in man. J. Biol. Chem., 1955, 212, 69.

9. Ahrens, E. H., Jr., Dole, V. P., and Blankenhorn, D. H., The use of orally-fed liquid formulas in metabolic studies. Am. J. Clin. Nutr., 1954, 2, 336.

10. Grossman, M. I., Moeller, H. C., Palm, L., and McDaniel, R., Unesterified fatty acid in blood serum. Federation Proc., 1955, 14, 65.

11. Shaffer, P. A., Antiketogenesis: its mechanism and significance. Medicine, 1923, 2, 375.

12. Banting, F. G., Best, C. H., Collip, J. B., Campbell, W. R., and Fletcher, A. A., Pancreatic extracts in the treatment of diabetes mellitus. Canad. M. A. J., 1922, 12, 141.

13. Bönniger, M., and Mohr, L., Untersuchungen über einige Fragen des Hungerstoff wechsels. I. Die Säurebildung im Hunger. Ztschr. f. exper. Path. u. Therap., 1906, 3, 675.

14. Anderson, A. B., and Anderson, M. D., The effect of adrenaline on ketosis in phloridizinised and normal rats. Biochem. J., 1927, 21, 1398.

15. Association of Life Insurance Directors and Actuarial Society of America, New York, 1912. Cited by Duncan, G. G., Diseases of Metabolism, Philadelphia, W. B. Saunders, 1942, p. 938. 